\author{
Cadernos de \\ ESTUDOS LINGUIISTICOS - (58.1), Campinas, pp. 7-24 - jan./abr. 2016
}

\title{
ESTUDOS DISCURSIVOS DA INTOLERÂNCIA: O ATOR DA ENUNCIAÇÃO EXCESSIVO
}

\author{
DIANA LUZ PESSOA DE BARROS*
}

\begin{abstract}
RESUMO: Este trabalho tenta sustentar as hipóteses de que os discursos intolerantes consideram o "diferente" como o que rompe pactos e acordos sociais, por não ser humano, por ser contrário à natureza, doente e sem ética ou estética, e que, por isso mesmo, é temido, odiado, sancionado negativamente e punido. Por sua vez, os discursos de aceitação e inclusão, que a eles se contrapõem, são elaboradoscom estratégias, temas e valores contrários aos acima. Seus contratos são os de multilinguismo, mestiçagem, diversidade sexual, pluralidade religiosa, e não mais de pureza das línguas, de branqueamento da sociedade, de heterossexualidade, de identidade religiosa. A partir daí, examina, especificamente, os discursos intolerantes de sites e blogs da internet, que se caracterizam como discursos do excesso, ou mesmo pela exacerbação do excesso, e por se apresentarem, sobretudo, como discursos de intolerância ao intolerável.Essa intensificação do excesso decorre dos traços específicos dos discursos na internet e, ainda, de procedimentos discursivos diversos, dentre os quais se destacam a forte figurativização dos temas e o emprego de recursos retóricos, como o do argumento do excesso, com suas hipérboles, metáforas e metonímias.
\end{abstract}

Palavras-chave: Intolerância; Inclusão; Semiótica; Discursos do excesso.

ABSTRACT: This paper represents an attempt to defend the hypothesis that in intolerant discourses the "different" is considered to be the one who break pacts and social agreements, since the different is non human, against nature, sick, with no ethics or aesthetics, being, therefore, hated, feared, sanctioned negatively and punished. In turn, acceptance discourses, which are in direct opposition to the precious type of discourse, are elaborated with strategies, themes and values contrary to those mentioned above. The contracts established in acceptance discourses are the ones of multilingualism, blended races, sexual diversity, religious plurality, and not those of language purity, Caucasian society, heterosexuality, and religious identity. With this background, this paper examines intolerant discourses in websites and Internet blogs, which are characterized as the discourse of the excessive, and of the exacerbation of the excess, and, above all, discourses of intolerance against the intolerable. This intensification of the excess follows from specific traits of Internet discourses and, still, of a variety of discourse procedures, among which are strong figurativization of themes and the employment of rhetorical devices, such as the argument of the excess, in hyperboles, metaphors, and metonymies.

Keywords: intolerance; acceptance; semiotics; discourse of the excess.

* Professora na Universidade Presbiteriana Mackenzie - UPM e na Universidade de São Paulo - USP, Bolsista de Produtividade em Pesquisa do CNPq. E-mail: dianaluz@mackenzie.br; dianaluz@usp.br 


\section{INTRODUÇÃO}

Desenvolvemos, em estudos anteriores (BARROS, 2008a, 2008b, 2008c, 2011) uma proposta teórica e metodológica para o exame da organização narrativa e discursiva dos discursos intolerantes e preconceituosos, no âmbito da semiótica discursiva, com quatro aspectos principais: a organização narrativa dos discursos intolerantes como discursos de sanção; seu caráter fortemente passional, com ênfase nas paixões do medo e do ódio; os percursos temáticos e figurativos da diferença; a organização tensiva desses discursos.

Do ponto de vista da organização narrativa, o discurso intolerante é, sobretudo, um discurso de sanção aos sujeitos considerados como maus cumpridores de certos contratos sociais: de branqueamento da sociedade, de pureza da língua, de heterossexualidade, de identidade religiosa e outros. Esses sujeitos são, portanto, no momento do julgamento, reconhecidos como maus atores sociais, maus cidadãos - pretos ignorantes, maus usuários da língua, índios bárbaros, judeus perigosos, árabes fanáticos, homossexuais promíscuos - e punidos com a perda de direitos, de emprego ou, até mesmo, com a morte.

Quanto às modalizações, aspectualizações e moralizações discursivas, de que decorremas paixões construídas nos discursos, pode-se observar que os discursos intolerantes são fortemente passionais, que seus sujeitos são sempre sujeitos apaixonados e que predominam, nesses discursos, dois tipos de paixões - as paixões malevolentes (antipatia, ódio, raiva, xenofobia, etc.) ou de querer fazer mal ao sujeito que não cumpriu os acordos sociais acima mencionados (GREIMAS,2014 [1983]; 1993 [1991]), e as paixões do medo do "diferente" e dos danos que ele pode causar. O sujeito do ódio em relação ao estrangeiro, ao diferente, aos "maus" usuários da língua, é também o sujeito do amor à pátria, à sua língua, ao seu grupo étnico, aos de sua cor, à sua religião, ou seja, complementam-se as paixões malevolentes do ódio em relação ao "diferente" e as paixões benevolentes do amor aos "iguais". Essa é a fase do preconceito, a primeira fase da intolerância e a mais passional. A segunda fase, a da intolerância propriamente dita, é aquela em que o sujeito preconceituoso passa à ação, ou seja, age contra o outro, que ele considera o causador de suas perdas e que odeia. As ações são as ações apaixonadas de vingança ou de revolta, que se distinguem, da justiça desapaixonada.Em relação às paixões do medo (ver LOTMAN, 1981, FIORIN, 1992), é preciso dizer que, entre os diferentes tipos de medo, é o medo do outro, de suas ações e das privações por ele ocasionadas que, geralmente, caracteriza o discurso intolerante. As paixões do medo do diferente provocam as paixões do ódio ou somam-se a essas paixões malevolentes e fazem crescer de intensidade os percursos passionais e as ações intolerantes.

Os temas e figuras dos discursos intolerantes estão relacionados à oposição semântica fundamental entre a igualdade ou identidade e a diferença ou alteridade e, a partir daí, esses discursos constroem alguns percursos temáticos e figurativos, de que são ressaltados quatro: a desumanização do "outro", a que são atribuídos traços físicos e características comportamentais de animais ou de objetos, desumanizando-o; a "anormalidade" do diferente, que é e age contra a "natureza"; o caráter doentio da diferença, tanto do ponto de vista físico, quantocognitivo 8 
Cadernos de ESTUDOS LINGUÍSTICOS (58.1) - jan./abr. 2016

e mental, em que o diferente é considerado como doente, como ignorante e pouco inteligente, como louco e também, enquanto "doente", como feio, como esteticamente condenável em oposição aos sadios de corpo e mente; a imoralidade do "outro", a sua falta de ética.

Em síntese, os discursos intolerantes consideram o "diferente" como aquele que rompe pactos e acordos sociais, por não ser humano, por ser contrário à natureza, por ser doente e sem ética ou estética, e que, por isso mesmo, é temido, odiado, sancionado negativamente e punido. Por sua vez, os discursos de aceitação e inclusão, que a eles se contrapõem, são ou devem ser elaborados com estratégias, temas e valores contrários aos descritos acima. Seus contratos são os de multilinguismo, de mestiçagem, de diversidade sexual, de pluralidade religiosa, e não mais de pureza das línguas, de branqueamento da sociedade, de heterossexualidade, de identidade religiosa. Neles, o "diferente", o "outro" não é mais considerado como aquele que rompe pactos e acordos sociais, mas ao contrário, é visto como aquele que garante novas e promissoras relações sociais. A sanção positiva e as paixões benevolentes, que nos discursos intolerantes só se aplicam aos "iguais", a "nós", se estendem, assim, aos diferentes, a "eles".

Se enfatizamos, em nossa proposta, em um primeiro momento da pesquisa, a organização narrativa e discursiva da intolerância, examinamos, em seguida, (BARROS, 2014) a organização tensiva desses discursos, com base principalmente no artigo de Zilberberg (2004) sobre as condições semióticas da mestiçagem, ea partir, sobretudo, da sintaxe que opera por triagem e por mistura na dimensão da extensidade dos discursos.O exame da organização tensiva dos discursos intolerantes alargou seu campo de aplicação e mostrou, com mais clareza e segurança teórica, as relações e os graus intermediários entre os discursos intolerantes e os de inclusão, e, com os limites extremos de triagem e de mistura, as formas mais violentas de intolerância ou a perda de identidade e de sentido no discurso. Neste artigo, interessam-nos as formas mais violentas de intolerância.

A partir dessa proposta teórica e metodológica, de que apresentamos aqui apenas algumas pinceladas, trataremos neste artigo dos casos de exacerbação da intolerância, que ocorrem, principalmente, nos discursos da internet, e, sobretudo, nos blogs. Para tanto, vamosrecuperar duas de nossas reflexões sobre casos específicos de intolerância, a primeira,nos discursos políticos, a segunda,nos discursos na internet. Nosso objetivo é, apartir daí, poder dizer alguma coisa sobre a construção discursiva do ator da enunciação, elaborada nos discursos do excesso, em que a intolerância é fortemente exacerbada. Tudo indica que a exacerbação da intolerância é uma estratégia de construção da imagem desse ator "exuberante".

\section{ALGUMAS REFLEXÕES SOBRE AINTOLERÂNCIA NOS DISCURSOS POLÍTICOS}

Em estudos sobre a intolerância nos discursos políticos chamou-nos a atenção (BARROS, 2013), o uso muito frequente de discursos intolerantes como estratégia de discursos sociais diversos, e políticos em particular. É essa a questão que nos interessa retomar aqui. 
Nesses estudos apresentamos, a partir de trabalhos de Eric Landowski (1979, 1982, 1992 e 1997) e de José Luiz Fiorin (1988a e 1988b), três características fundamentais do discurso político: ser um discurso do poder, ou seja, o sujeito político é modalizado pelo poder, e seu discurso é um discurso de busca do poder como valor ou de sua conservação, reconhecimento e reforço; ser um discurso do saber, isto é,para mostrar-se confiável, e bem exercer a persuasão, o sujeito político apresenta-se também como sujeito do saber, seja do saber sobre a sociedade, "a realidade" e os acontecimentos, seja do saber-fazer; ser um discurso em que há um jogo interacional de posições e atribuições de poder entre enunciador e enunciatário, que ocupam assim os lugares narrativos tanto de destinador quanto de destinatário do poder e do saber.

O uso de discursos intolerantes como estratégia de discursos políticos, como plataforma política interessou-nos principalmente porque os dois tipos de paixões que definem os discursos intolerantes, o ódio e o medo, são, em geral, moralizados negativamente pela sociedade, e as paixões contrárias, de amor e de coragem, fortemente valorizadas. Apesar disso, o ódio e o medo do outro (que não cumpriu acordos sociais) e das perdas que ele poderá ocasionar (falta de emprego, de moradia, de vaga na universidade, de segurança, etc.), segundo os simulacros construídos, servem como justificativa para as ações intolerantes e como estratégia de persuasãoem muitos discursos políticos.

O sujeito político constrói-se, nesse caso, como um ator(ou com um éthos) intolerante de um tipo particular, pois elabora um discurso de "intolerância ao intolerável", segundo certos valores. São bons exemplos falas, divulgadas na mídia, do deputado federal Jair Bolsonaro, que recebeu 120.646 votos na eleição que precedeu as manifestações a seguir citadas:

No quadro "O Povo Quer Saber", do programa CQC, da TV Bandeirantes, a cantora Preta Gil perguntou como ele [deputado Jair Bolsonaro] reagiria se seu filho se apaixonasse por uma negra.

O parlamentar, que tem um extenso histórico de polêmicas relacionado a direitos civis e humanos, respondeu: "Preta, não vou discutir promiscuidade com quem quer que seja. Eu não corro esse risco e meus filhos foram muito bem educados. E não viveram em ambiente como lamentavelmente é o teu".

Após o programa ir ao ar na noite de anteontem, Bolsonaro tentou se justificar. Disse que, na realidade, pensou que a pergunta se referisse a um relacionamento gay (...). "Essa se encaixa na resposta que eu dei. Para mim, ser gay é promíscuo, sim".(Folha de S. Paulo, 30/03/2011, p. C1).

Os discursos do deputado e de outros políticos mostram que eles usam discursos considerados intolerantes e, em alguns casos, contrários à lei (racistas, por exemplo), para construir uma imagem de político intolerante ao que considera, assim como seu partido e seu eleitor, intolerável. A aprovação do destinatário, que atribui poder aos sujeitos políticos e em nome de quem eles falam e agem, aparece, por exemplo, na votação expressiva do deputado Bolsonaro, na eleição de 2010, acima mencionada, e, principalmente, na de 2014, em que obteve mais de 464 mil votos, e também em cartas de leitores encaminhadas aos jornais, como a que segue: 
Quero parabenizar o deputado Bolsonaro pela iniciativa de mostrar o lado das pessoas que prezam a família e a moral, tão esquecidas nesta sociedade que valoriza as aberrações que afrontam os que defendem a decência (Folha de S. Paulo, 12/05/2011, p. A3).

O discurso preconceituoso usado nesses textos políticos mostra, por exemplo, que negros e homossexuais não cumpriram os contratos de uma sociedade branca e heterossexual, são promíscuos e contrários aos "bons costumes", e merecem, portanto, o medo e o ódio que o sujeito intolerante lhes dedica. O discurso político constrói-se, assim, como o discurso de um sujeito que teve a coragem de manifestar sua intolerância aos que não merecem ser tolerados, e é, por isso mesmo, moralizado positivamente. Daí o discurso de "intolerância ao intolerável", daí a votação significativa e as cartas de aprovação de leitores.

Esse tipo de discurso político cria justificativas para o ódio ao diferente e contribui para seu crescimento, da mesma forma que procura incutir o medo dos danos que esse diferente pode causar aos filhos da boa família brasileira, tornandoos, por exemplo, "presas fáceis para pedófilos".

\section{ALGUMAS REFLEXÕES SOBRE AINTOLERÂNCIANOS DISCURSOS NA INTERNET}

Em estudos sobre os discursos na internet procuramos apontar as particularidades desses discursos e a relação entre essas características e a construção da intolerância. Duas características foram ressaltadas: a definição dos discursos na internet quanto às modalidades falada e escrita; sua organização enunciativa e veridictória, sobretudo nos discursos das redes sociais.

No texto "Entre a fala e a escrita: algumas reflexões sobre as posições intermediárias" (BARROS, 2000) apontamos as dificuldades de se fazer uma distinção rígida entre escrita e fala e a existência de certa continuidade e de posições intermediárias entre os pontos extremos em que se caracterizam idealmente língua falada e língua escrita. Os textos da internet exemplificaram boa parte desses pontos intermediários entre fala e escrita "ideais", nos três aspectos observados no artigo mencionado: as características temporais, espaciais e actoriais do discurso falado e escrito. Os discursos na internet foram, a partir daí, caracterizados como um complexo, tanto fala, quanto escrita. O termo complexo foi tratado por Greimas e retomado, mais recentemente, com muito sucesso, nos trabalhos de Claude Zilberberg(2004, 2006a, 2006b). Definida pela complexidade, a comunicação na internet é, ao mesmo tempo, próxima e distante; descontraída e formal; incompleta e completa; subjetiva e objetiva. É preciso observar, porém, que a complexidade de termos contrários, comodescontraída e formal ou subjetiva e objetiva, não é possível nos discursos implicativos ou causais, mas pode ocorrer nos discursos concessivos. O discurso na internet deve ser entendido, portanto, como um discurso de conjunção concessiva entre contrários: fala (próxima, descontraída, incompleta, subjetiva), embora escrita (distante, formal, completa, objetiva), ou escrita, embora fala. 
Por isso, o discurso na internet tem seus sentidos exacerbados, já que engloba as possibilidades de interação das duas modalidades. Resultam daí sua interatividade intensa, a longa conservação de seus conteúdos e a grande extensão de seu alcance. Em outras palavras,ela dá maior tonicidade e intensidade a alguns atributos da fala, como a interatividade, e, ao mesmo tempo, aumenta a extensão e o alcance comunicacional da escrita.São essas as características de base dos discursos na internet -interatividade exacerbada, longa duração ou permanência dos discursos e grande extensão de seu alcance comunicacional e elas decorrem, principalmente, da complexidade entre a fala e a escrita, mas também de outras formações de termos complexos (público vs. privado, multibreagens, etc). Com isso, o discurso na internet permite e facilita a construção e a propagação de ondas de intolerância e, sobretudo, acentua a permanência, a extensão e o caráter passional e sensorial da intolerância.

A segunda questão é a da organização enunciativa e veridictória dos discursos na internet, a partir de que se pode dizer alguma coisa sobre a interpretação dos discursos como verdade ou falsidade, sobre os problemas de autoria e anonimato e sobre o caráter público e privado desses discursos. Diremos aqui apenas algumas palavras sobre a veridicção e a relação entre o público e o privado.

Em relação à veridicção, os discursos da internet são, em geral, considerados verdadeiros, ou seja, que parecem e são verdadeiros, e, mais do que isso, que eles são discursos que desmascaram a mentira ou revelam o segredo. A interpretação como discurso verdadeiro e também o desmascaramento da mentira e a revelação do segredo decorrem do efeito de sentido de grande quantidade de saber armazenado pela internet e do de interatividade acentuada. O destinador desses discursos é colocado na posição de sujeito do saber e seu destinatário, devido à interatividade intensa já mencionada, deles se considera, em boa parte, também como "autor-destinador". Esse destinatário, assim construído, acredita e confia nos discursos que também são "seus".

As análises já efetuadas indicam que, tal como ocorre em relação às modalidades falada e escrita, o discurso da internet define-se pelo termo complexo"embora privado, público", ou, com inversão de equilíbrio, "embora público, privado", ou seja, pela ruptura da oposição entre privado e público. O domínio do público é regulamentado pela lei, pela regra, o do privado é o das variações e preferências individuais. Na internet, preferências individuais, próprias da privacidade do sujeito, são expostas e submetidas às leis públicas ou se tornam regras públicas. Daí as humilhações e suicídios das jovens expostas na "vingança pornô" e a preocupação em monitorar a imagem e a reputação do sujeito na internet. Essa continuidade entre o público e o privado é, provavelmente, resultante do fato de o sujeito do discurso da internet, dotado do poder que a interatividade intensificada, a extensão e propagação alargadas, o saber e o anonimato lhe dão, coloca-se como um homem público, que pode, sem riscos, expor suas preferências, sentimentos e emoções privadas e fazer delas regras públicas. 
Em síntese, algumas das principais características dos discursos na internet são: exacerbação da intensidade na interação e da extensão na duração e alcance desses discursos (devido à sua complexidade, entre a fala e a escrita); negação da oposição entre público e privado (devido à formação do complexo público/ privado); instalação do sujeito discursivo como "homem público", sujeito do poder; e também como sujeito confiável, pois apresenta a verdade e o saber, mas sem responsabilidade sobre o que diz. Complexidade, no sentido semiótico do termo, parece ser o elemento definidor dos discursos da internet.

A internet não é a causa do preconceito e da intolerância, mas os discursos nela construídos, pelas características discursivas apontadas, facilitam, desencadeiam, incentivam ou escancaram a produção de discursos agressivos, intolerantes e preconceituosos e sua intensa e extensa divulgação.

\section{OS DISCURSOS DO EXCESSO}

Os discursos intolerantes em geral e os discursos na internet, também em geral, caracterizam-se pelo excesso: de intensidade, de tensão passional, de extensão, de complexidade. Dessa forma, os discursos intolerantes e preconceituosos na internet ampliam esses excessose constroem asondas, ou melhor, os tsunamis de ódio de que imprensa e sociedade tanto falam nos tempos atuais. Nossa intenção aqui é ir um pouco mais longe e falar do excesso desse excesso, que já estava ampliado na internet, e que caracteriza muitos desses discursos, e mostrar que essa exacerbação do excesso decorre de procedimentos discursivos retóricos e constróium tipo específico de ator da enunciação. Já havíamos mostrado acima que, nos discursos políticos, o uso da intolerância como plataforma marcaum tipo particular de intolerância: a intolerância ao que não pode ser tolerado, ao intolerável (nos exemplos citados, ser homossexualou negro, por colocar em risco os pactos sociais da família brasileira e da constituição de uma sociedade branca). Pretendemos, agora, mostrar que isso também ocorre no que estamos chamando de discurso do excesso exacerbado e refletir sobre a construção do ator da enunciação, da imagem discursiva do enunciador, decorrente dessas estratégias de exacerbação do excesso.

Na Semiótica discursiva, o sujeito da enunciação define-se, sintaticamente, como um actante da enunciação e, semanticamente, como um ator da enunciação:

Do ponto de vista da produção do discurso, pode-se distinguir o sujeito da enunciação, que é um actante implícito, logicamente pressuposto pelo enunciado, do ator da enunciação: neste último caso, o ator será, digamos, "Baudelaire", enquanto se define pela totalidade de seus discursos. (GREIMAS e COURTÉS, 2008: 45).

A construção sintática do actante da enunciação diz respeito ao emprego das categorias enunciativas de pessoa (ver, a respeito, FIORIN, 1996) e, também, às relações narratológicas que se estabelecem entre enunciador e enunciatário. Com o emprego das categorias enunciativas de pessoa são produzidos nos discursos efeitos de aproximação da enunciação, devido ao uso, em geral, do "eu" discursivo, ou de distanciamento da enunciação, com o emprego, principalmente, do "ele" do discurso. 
Já a constituição do ator da enunciação depende dos papéis que o sujeito assume no espetáculo enunciativo e que lhe dão identidade, estilo e corpo e o preenchem com crenças e valores, modos de ser e de fazer, decorrentes de papéis temáticos e figurativos (ver, a respeito, DISCINI, 2003). A semiótica desenvolveu, na semântica do discurso, os conceitos de tematização e de figurativização: os temas, abstratos, disseminam-se pelo texto em percursos que, por sua vez, podem ser "concretizados" sensorialmente pelo procedimento de figurativização. Os temas e figuras são determinados sócio-historicamente e asseguram o caráter ideológico desses discursos (FIORIN,1988b, p. 1-19). Os temas e figuras, dessa forma, trazem ao ator da enunciação as marcas de sua inserção sócio-histórica e ideológica, e, além disso, como as figuras investem sensorialmente os temas, dãolhe corpo. O exame dos atores da enunciação é, portanto, o modo como os estudos semióticos procuram dar à enunciação identidade corporal e sócio-histórica.

Finalmente, para a determinação desse ator da enunciação, é preciso considerar ainda as relações entre discursos, que permitem diferenciar o ator da enunciação do ator da narração. A identidade do narrador, definida por um único discurso, distinguese da do enunciador, caracterizada por um conjunto ou uma totalidade de discursos, conforme aparece na citação de Greimas e Courtés, acima exposta.

Vejamos qual imagem de si o sujeito da enunciação constrói ao produzir discursos de excesso exacerbado e com que procedimentos essa imagem se elabora. Para a análise desses discursos vamos partir, sobretudo, dos estudos de Fiorin (2014 e 2015) sobre a retórica, na perspectiva da semiótica discursiva. Os procedimentos usados são, principalmente, os da tematização e figurativização do discurso, em geral, e, em especial, o argumento do excesso (FIORIN,2015: 222), que está relacionado, em primeiro lugar, à figura da hipérbole (2014: 75-77). Sobre o argumento de excesso, diz Fiorin que ele "consiste em exagerar retoricamente um ponto de vista com a finalidade de levá-lo à aceitação" (2015: 222). A hipérbole, por sua vez, é definida como um tropo em que há aumento de intensidade semântica, ou seja, em que se procura dizer uma coisa de maneira mais forte, para chamar a atenção e mais bem persuadir o destinatário. Procuraremos mostrar, além disso, que o que estamos chamando de discurso do excesso exacerbado usa em seus argumentos do excesso não apenas a figura da hipérbole, mas outros tropos. Segundo Fiorin (2015:28-33), os tropos se classificam porconcentração e condensação ou por expansão e difusão semânticas, já que são operações enunciativas de intensificaçãodos sentidos e que produzem o efeito de uma "impropriedade"semântica. Quaisquer figuras podem ser, portanto, usadas nos discursos do excesso. Nossas análises mostram a predominância da hipérbole e da metonímia, entre os tropos por expansão semântica, e da metáfora, entre os tropos por concentração semântica.

Vamos examinar alguns exemplos desses discursos de exacerbação do excesso, encontrados na internet em blogs, sites ou notícias, publicados no segundo semestre de 2015 e no primeiro de 2016. Boa parte deles foi obtida no blog Reis do Camarote e no site "Tio Astolfo, em prol da filosofia do estupro, um site de Robson Otto Aguiar”, que não estão mais na web, mas podem ser encontrados, reproduzidos, em outros blogs ou sites. Esses blogs e sites dialogam entre si, copiam coisas uns dos outros e têm links, uns para os outros. 

racista:

Mulheres que usam anticoncepcional são vagabundas

Abusar de meninas não é pedofilia, elas vieram ao mundo para isso.

Colocando mulheres (seres inferiores) em seu devido lugar

Penetração corretiva em mulheres lésbicas

Salve uma mulher do homossexualismo e da Aids

Mulheres gostam de apanhar

Esfaqueando uma mulher sem usar as mãos: tortura psicológica e indução ao suicídio.

\section{O corpo dos textos mostra os percursos temáticos e figurativos desses discursos:}

Estuprar lésbicas é um esporte saudável que revigora a alma e libera a adrenalina, todos saem ganhando. Sim, todos saem ganhando, a família dela ao ver a filha corrigida do mau caminho, eu se tivesse uma filha retardada chupadora de "ppk", com certeza agradeceria o nobre varão que fez o favor, mas acho que a teria matado e estuprado antes disso e foi de fato o que eu aconselhei o pai de uma dessas a fazer e assim ele fez.

Quando uma feminista vadia é estuprada porque anda de roupa curta em uma viela cheia de marginais, é um completo absurdo.

Lembre-se que estupro tem a ver com violência. Se a vadia quiser fazer sexo consensual, está errado. Ela tem que negar. É por isto que você precisa ser violento. Em um momento sozinho, simplesmente pegue-a a força, tire a porra da roupa dela e a violente.

Nunca se esqueçam: mulheres são objetos.

Quando você estupra uma mulher, você está ensinando a ela o seu papel na sociedade, a impedindo de se tornar homossexual e se contaminar com uma DST. Você também está prevenindo que ela satisfaça seu instinto procurando marginais. Resumidamente, você está cumprindo o seu papel como um homem branco, colocando a fêmea no seu devido lugar.

A adolescência é marcante na vida da mulher, onde ela começa a utilizar maquiagem e a se vestir como uma vagabunda. A única maneira de corrigir esta conduta imoral é estuprando violentamente a vadia, de maneira a traumatizá-la para o resto da vida. Quanto mais cedo você estupra a mulher, menor a probabilidade dela se contaminar com HIV como também menor a probabilidade dela se engravidar ou 'sujar a boceta' com um marginal.

Isto mesmo, filho da puta, com uma mão no pescoço da vadia, vá deslizando a faca pelas pernas dela. Neste momento geralmente a garota começa a chorar. Começa a implorar e a balbuciar em lágrimas. Não dê uma foda para o que ela disser, apenas lembre-se das vezes que foi simpático com vagabundas deste tipo e elas te desprezaram. Agora, agora o jogo mudou, quem está no controle da situação é você e não ela.

Quando você mantém uma vadia desta na mira de sua arma não há "sororidade", não há "igualdade", não há absolutamente nada mais nada. Tudo o que há é a natureza crua e pura, você, o sexo superior, fazendo o que lhe é de direito.

A mulher serve apenas para sexo, se ela não está fazendo sexo, não tem utilidade alguma na sociedade. Mulheres se comparada a homens são fracas e burras. São apenas pedaços de carne que homens utilizam para vir ao mundo. 
A típica estudante de Direito é aquela vadia patricinha de classe média alta, que quer ser Juíza, Promotora ou Delegada da PF. Em qualquer civilização decente esta vagabunda não deveria nem estar sentada na merda de um banco de faculdade, deveria estar na cozinha lavando as cuecas de seu homem ou fazendo a porra da comida.

Mulheres na universidade são tão úteis quanto macacos aprendendo física quântica. Já provamos inúmeras vezes neste blog que mulheres são um atraso científico.

Nós não odiamos as mulheres, nós as amamos, por isto estamos fazendo o que elas querem, querem ser mortas e estupradas.

Os temas desenvolvidos são, em geral, todos os que apontamos como característicos dos discursos intolerantes:

- a inferioridade da mulher é tematizada pela imoralidade (são vadias e vagabundas, vivem em orgias), pela anormalidade (são "retardadas"), pelo caráter doentio (são doentes, feias, burras, ignorantes: "Mulheres se comparadas a homens são fracas e burras.") e pela desumanização ("mulheres são objetos", e objetos inúteis - "A mulher serve apenas para sexo, se ela não está fazendo sexo, não tem utilidade alguma na sociedade", e são também animalizadas, como fêmeas que agem por instinto, como macacos - "Você também está prevenindo que ela satisfaça seu instinto procurando marginais"; "Mulheres na universidade são tão úteis quanto macacos aprendendo física quântica. Já provamos inúmeras vezes neste blog que mulheres são um atraso científico"), daí ela precisar ser "corrigida", ensinada e punida ("Quando uma feminista vadia é estuprada porque anda de roupa curta em uma viela cheia de marginais, é um completo absurdo"; "Lembre-se que estupro tem a ver com violência. Se a vadia quiser fazer sexo consensual, está errado. Ela tem que negar. É por isto que você precisa ser violento"); dessa forma, a inferioridade da mulher contrapõe-se àsuperioridade do homem - forte, viril, dominador, inteligente, capaz, ético ("Quando você mantém uma vadia desta na mira de sua arma não há "sororidade", não há "igualdade", não há absolutamente nada mais nada. Tudo o que há é a natureza crua e pura, você, o sexo superior, fazendo o que lhe é de direito.");

- a homofobia é tematizada também pela imoralidade, pela anormalidade, pelo caráter doentio e pela animalização ("a filha corrigida do mau caminho"; "uma filha retardada"); há o mesmo cumprimento dos contratos sociais, da parte dos homens heterossexuais ("Estuprar lésbicas é um esporte saudável que revigora a alma e libera a adrenalina, todos saem ganhando; a família dela [...] com certeza agradeceria") e a mesma ruptura de acordos sociais por parte de mulheres e homossexuais; nos dois temas,a sanção pragmática ou punição maior e adequada é a morte e a sanção cognitiva, a humilhação - mulheres e homossexuais precisam ser humilhados, como uma forma de correção e para evitar a persistência no "erro" ("Quando você estupra uma mulher, você está ensinando a ela o seu papel na sociedade"; "Isto mesmo, filho da puta, com uma mão no pescoço da vadia, vá deslizando a faca pelas pernas dela. Neste momento geralmente a garota começa a chorar. Começa a implorar e a balbuciar em lágrimas"; "A única maneira de corrigir esta conduta imoral é estuprando violentamente a vadia, de maneira a traumatizá-la para o resto da vida");

- o racismo, finalmente, é tematizado, sobretudo, pelo caráter doentio (o negro é feio, e assim por diante), e pela animalização (cheira mal); o homem branco é valorizado em detrimento do negro.

O homem branco e heterossexual tem, portanto, a "missão" de garantir os contratos sociais de heterossexualidade, de embranquecimento da sociedade e de superioridade do homem em relação à mulher, assegurando os papéis e os direitos sociais diferentes de homem e de mulher, de branco e de negro, de heterossexual e de homossexual.Ele não pode, por dever social e moral, tolerar o que é intolerável. 
Cadernos de ESTUDOS LINGUÍSTICOS (58.1) - jan./abr. 2016

Trata-se, assim, de um discurso intolerante, mas em relação ao que a sociedade não pode tolerar: a imoralidade das mulheres, ser negro, ser homossexual, defender a igualdade de direitos entre homens e mulheres, como fazem as feministas, não reconhecer a superioridade e os direitos dos homens brancos e heterossexuais: "Quando você estupra uma mulher, você está ensinando a ela o seu papel na sociedade, a impedindo de se tornar homossexual e se contaminar com uma DST. [...] Resumidamente, você está cumprindo o seu papel como um homem branco, colocando a fêmea no seu devido lugar".

Os textos esclarecem, portanto, que os homens que agridem, violentam e matam mulheres, negros e homossexuais estão cumprindo, como "nobres varões",um contrato social, estão fazendo um "favor" à sociedade e merecem, portanto, a sanção positiva do reconhecimento. As mulheres, os homossexuais e os negros, ao não cumprirem certos contratos sociais, são os responsáveis pela merecida sanção negativa que sofrem: as mulheres, por exemplo,"querem ser mortas e estupradas".

Para fazer desse discurso preconceituoso e intolerante um discurso do excesso exacerbado e que, portanto, tem maior poder persuasivo, são usados recursos diversos de argumentação e figurativização. Vejamos alguns deles.

O tema da imoralidade das mulheresé figurativizado pelo uso de roupas curtas e inadequadas, pela maquiagem, pelas orgias de que participam, pelas relações que mantêm com marginais, pelas doenças sexuais que adquirem, pela gravidez indesejada, por usarem anticoncepcionais,por serem feministas e por abortarem. A desumanização delas recebe, entre outras, as figuras de objetos e de "pedaços de carne", que sevem apenas para a procriação, e opõe-se, por exemplo, ao caráter humano do homem branco e heterossexual que tem alma, revigorada pelo estupro de lésbicas. É clara a oposição entre a carne e a alma ou o espírito, nesse jogo de figuras.A anormalidade da homossexualidade é representada por relações sexuais "contrárias à natureza". O negro recebe figuras visuais e olfativas, sobretudo, de cor e de cheiro. A figurativização dá concretude e sensorialidade ao tema e, no caso, procura obter efeitos corporais de asco, de nojo pelos que, por isso mesmo, não podem ser tolerados.

$\mathrm{O}$ argumento do excesso está fundamentado, como diz Fiorin, no exagero deum ponto de vista. Os discursos em exame fazem isso, exageram, com diferentes recursos, os pontos de vista que acima foram elencados. Um dos recursos para a obtenção desse efeito de "exagero" é a figurativização examinada. Além disso, foram usadas muitas figuras retóricas, tanto de concentração, quanto de expansão semântica para essa intensificação discursiva.

Comecemos com a hipérbole, entre as figuras de expansão semântica. Em "[as mulheres] querem ser mortas e estupradas", "[o pai] teria matado e estuprado [a filha homossexual] antes disso"; "Mulheres que usam anticoncepcional são vagabundas"; "Abusar de meninas não é pedofilia, elas vieram ao mundo para isso"; "Mulheres gostam de apanhar"; “[...] não há absolutamente nada mais nada. Tudo o que há é a natureza crua e pura", diz-se mais para enfatizar o que está sendo dito. Há generalizações excessivas (Todas as mulheres gostam de apanhar), há exagero na reação do pai (que estupra e mata filha), no dizer 
o que as mulheres querem (ser mortas e estupradas), na forma de tratar a homossexualidade (retardamento) ou ainda na negação com um "não" e dois "nadas" e na ressignificação da expressão pronta "verdade nua e crua" em "verdade crua e pura", que acentua a pureza e a legitimidade das ações do homem que domina e violenta a mulher. Além da hipérbole, os textos trazem algumas metonímias, ainda entre os tropos por expansão semântica, e um maior número de metáforas, em que há concentração semântica. Em "filha retardada chupadora de "ppk" temos uma metonímia para lésbica; em "revigora a alma", a parte "alma" é usada pelo todo "homem", para reforçar que o estupro não traz apenas satisfação física, mas também "espiritual"; em "esta vagabunda não deveria nem estar sentada na merda de um banco de faculdade", sentarem um banco da faculdade é metonímia para fazer um curso superior, desvalorizando com isso a mulher que está na universidade. Já em "Estuprar lésbicas é um esporte saudável"ocorre uma comparação metafórica, em que se estabelece uma relação de similaridade entre o estupro e o esporte, que produz o efeito de sentido de que ambos são "saudáveis" para todos os envolvidos e para a sociedade; em o "nobre varão", há uma relação de semelhança metafórica entreo nobre viril e de tradição e o homem branco e heterossexual; em "Mulheres na universidade são tão úteis quanto macacos aprendendo física quântica", comparam-se mulheres com macacos, para mostrar a animalização da mulher e sua pouca inteligência; em "[mulheres] são apenas pedaços de carne" estabelece-se similaridade entre mulher e pedaço de carne de açougue, para fazer da mulher um objeto e também pura carne sem espírito.

Deve-se observar ainda que o argumento do excesso seve-se, no caso, também de "palavrões" ou de termos considerados vulgares, em xingamentos e ofensas próprios do discurso da descortesia, que ameaça romper a interação como uma forma de reforçá-la. Uma última menção à intertextualidade provocada pelo termo "sororidade" que aparece entre aspas no texto em exame. Sororidade significa relação de igualdade, pacto entre irmãs, mas, além disso, é um termo usado no discurso feminista, o que explica seu emprego aqui como uma alusão.

Caracterizado o discurso do excesso exacerbado no material examinado, antes de tratar especificamente da construção do ator da enunciação desse discurso intolerante, é preciso mostrar que, nos textos analisados,se desenvolve ainda outro tema e que, além disso, esse novo percurso temático engloba os demais, que foram, até o momento, observados. Em outras palavras, a inferioridade das mulheres, dos negros e dos homossexuais decorre, em boa parte, dofato de mulheres, negros e homossexuais serem intelectuais de esquerda ou de serem aceitos e defendidospor esses intelectuais. A intolerância mais exacerbada é dirigida assim aos "esquerdistas" e, sobretudo aos "intelectuais esquerdistas". Vejamos os exemplos que seguem, dos mesmos sites e blogs, nos mesmos dias (vários são de janeiro de 2016):

Como estuprar uma mulher na USPFFLCH: O guia definitivo

Este é um guia para você, calouro ou veterano de um dos cursos da POLI. Você, sujeito ALPHA que está cansado destes maconheiros esquerdistas pilantras querendo dizer como você deve viver sua vida, atrasando suas aulas, usando drogas e destruindo campos. 
Guia definitivo de como estuprar mulheres na Universidade de Brasília UNB

Este guia é para você, homem branco, que já está literalmente de saco-cheio desses coletivos feministas e esquerdistas enchendo o saco, fazendo greve e atrasando a merda do seu curso com pregação de marxismo cultural.

A real é esta, que se não fosse este estado social-democrata e esquerdista que protege vagabundas a custa do suor e do trabalho do homem branco, todas estas feministas já teriam sido estupradas e mortas pelos afro-cotistas que elas tanto defendem.

Como estuprar uma mulher no curso de Direito (da UFC)

Como todo curso de humanas, o curso de Direito está entulhado de vagabundas dadeiras e esquerdistas aidéticos viadões. Todos eles são feministas imbecis. Diferente da Engenharia, nesses cursos as provas consistem em "achismos" [...]. Basta ele citar filosofias marxistas do meio de um papel higiênico cheio de bosta para receber nota 10 nas provas que serão corrigidas por um pilantra que de doutor só tem a merda do título.

Está na hora de desmascarar a vigarice intelectual esquerdista. Ao nosso lado, temos nada menos que a religião que deu origem à civilização ocidental, o cristianismo. Ao lado dos esquerdistas o que eles tem? Sociólogos viados, ateus pilantras e feministas vadias.

Esse discurso preconceituoso e intolerante em relação aos "intelectuais esquerdistas" não é novo, mas assumiu outras feições e tornou-se mais excessivo e exacerbado com as possibilidades oferecidas atualmente pela internet, tal como discutimos acima. Já há muito tempo "comunista come criança". O filme "Trumbo. Lista negra" também oferece bons exemplos do preconceito justificado pelo rompimento de contratos sociais embasados nos chamados "valores americanos", na metade do século XX. Hoje, caminho semelhante foi tomado no Brasil pelos que passaram a odiar Chico Buarque.

Nos textos em exame podemos apontar comose constroem esses discursos de intolerância exacerbada em relação aos intelectuais e artistas de esquerda, nessa mistura com os vários tipos de discursos intolerantes examinados e com as mesmas estratégias de exagero e intensificação semântica.

Observe-se, em primeiro lugar, nas citações acima que as mulheres que devem ser estupradas, os homossexuais e os negros que merecem punição fazem parte de comunidades universitárias(USP, UNB, UFC) ou são nelas defendidos e bem aceitos (a defesa dos "afro-cotistas" pelas feministas de esquerda).

Em segundo lugar, os textos estabelecem distinção entre alunos e professores das áreas de humanidades (FFLCH-USP, Curso de Direito da UFC) e os de engenharia (POLI-USP, Engenharia da UFC), e o critério é que os de humanidades são "esquerdistas" e "falsos intelectuais":

Este é um guia para você, calouro ou veterano de um dos cursos da POLi. Você, sujeito ALPHA que está cansado destes maconheiros esquerdistas pilantras querendo dizer como você deve viver sua vida, atrasando suas aulas, usando drogas e destruindo campos.

Como todo curso de humanas, o curso de Direito está entulhado de vagabundas dadeiras e esquerdistas aidéticos viadões. Todos eles são feministas imbecis. Diferente da Engenharia, nesses cursos as provas consistem em "achismos"[...] 
Finalmente, em terceiro lugar, os discursos mantêm muitos dos temas e figuras caracterizadores dos discursos intolerantes e várias das estratégias usadas nos textos já examinados.

A intolerância em relação aos intelectuais de esquerda é tematizada principalmente pela imoralidade (são vagabundos, pilantras, vigaristas, vadios, promíscuos, drogados: “[...] o curso de Direito está entulhado de vagabundas dadeiras e esquerdistas aidéticos viadões."; “[...] coletivos feministas e esquerdistas enchendo o saco, fazendo greve e atrasando a merda do seu curso com pregação de marxismo cultural"; Você, sujeito ALPHA que está cansado destes maconheiros esquerdistas pilantras querendo dizer como você deve viver sua vida, atrasando suas aulas, usando drogas e destruindo campos"; "A real é esta, que se não fosse este estado socialdemocrata e esquerdista que protege vagabundas a custa do suor e do trabalho do homem branco, todas estas feministas já teriam sido estupradas e mortas pelos afro-cotistas que elas tanto defendem."); pelo caráter doentio (são ignorantes, burros, imbecis, aidéticos, doentes de corpo e mente: "[...] as provas consistem em "achismos [...]"; "Basta ele citar filosofias marxistas do meio de um papel higiênico [...]”; "Todos eles são feministas imbecis"; “[...] esquerdistas aidéticos viadões".); e pela anormalidade(não são civilizados, são ateus, são homossexuais: "Ao nosso lado, temos nada menos que a religião que deu origem à civilização ocidental, o cristianismo. Ao lado dos esquerdistas o que eles tem? Sociólogos viados, ateus pilantras e feministas vadias".).

A figurativização é menos acentuada do que no discurso da inferioridade das mulheres, mas também ocorre. Para o tema da imoralidade, há figuras da vida na universidade - com curso, campus, aula, destruídos, segundo o texto, pelos intelectuais de esquerda-, das drogas (maconha e outras), por eles consumidas, das "dadeiras"; para o da ignorância, burrice e imbecilidade, as figuras são as das provas, notas e títulos imerecidos, da greve, do atraso no curso, da pregação marxista.

O discurso do excesso exacerbado faz uso também das hipérboles, para reforçar seu ponto de vista, com o emprego de "todo, nada, tudo, só", em que há o exagero, por exemplo, de que todo sociólogo é homossexual e toda feminista vadia: [...] está cansado destes maconheiros esquerdistas pilantras querendo dizer como você deve viver sua vida, atrasando suas aulas, usando drogas e destruindo campos"; "Este guia é para você, homem branco, que já está literalmente de saco-cheio [...]”; “[...] custa do suor e do trabalho do homem branco [...]"; "[...] todas estas feministas já teriam sido estupradas e mortas pelos afro-cotistas que elas tanto defendem.";““[...] o curso de Direito está entulhado de vagabundas dadeiras e esquerdistas aidéticos viadões. Todos eles são feministas imbecis."; "Basta ele citar filosofias marxistas do meio de um papel higiênico [...] para receber nota 10 [...]"; "Ao nosso lado, temos nada menos que a religião que deu origem à civilização ocidental, o cristianismo."; "Sociólogos viados, ateus pilantras e feministas vadias". Entre as demais figuras, encontramse nos textos examinados algumas metonímias e metáforas, com os objetivos de produzir efeitos de excesso pela expansão e concentração semânticas:"“[...] com o suor do homem branco [...]" (em que suor tem relação metonímica com trabalho); "Basta ele citar filosofias marxistas do meio de um papel higiênico"; " [...] ]atrasando a merda do seu curso" (em que são comparados, metaforicamente, cursos da área 
Cadernos de ESTUDOS LINGUÍSTICOS (58.1) - jan./abr. 2016

de humanidades e filosofias marxistas com excrementos). As palavras ditas chulas, assim como gírias e expressões populares, são abundantemente usadas e contribuem bastante como a argumentação pelo excesso, que, nesse caso, caracteriza o discurso do exagero, mas também da descortesia.

O discurso do excesso exacerbado, conforme observado, não aceita o diálogo, a resposta, a polifonia, a polêmica de vozes. Monofônico e homogêneo, ele é discurso da verdade única e incontestável, da triagem levada às últimas consequências.

Zilberberg (2004, 2006a e 2006b) ao tratar das operações sintáticas de triagem e mistura, aponta os limites extremos da triagem, em que ocorrem as formas mais violentas de intolerância. Os valores de absoluto, de unicidade, de pureza e de exclusividade, próprios da triagem, podem ser exacerbados, como vimos ocorrer nos discursos em análise. Zilberberg afirma que o limite "natural" da triagem é a ausência de qualquer impureza, ou, em outras palavras, de qualquer diferença. Para tanto, a triagem é reiterada em uma triagem da triagem. Essa operação busca a "pureza da pureza" e, ao atingir esse limite, o de um mundo de excluídos, os discursos intolerantes provocam, muitas vezes, a violência exacerbada, como a dos genocídios. É isso que acontece nos discursos intolerantes do excesso exacerbado. Além da triagem que caracteriza a intolerância, esses discursos operam novas triagens ao empregarem o argumento do excesso exacerbado, com os recursos linguísticos e discursivos examinados e provocam violência sem limites. Depois dessas triagens das triagens, cujos procedimentos foram aqui apontados, só restam os homens brancos, cristãos, heterossexuais, de direita e das áreas das ciências exatas. E um mundo de excluídos.

\section{CONSIDERAÇÕES FINAIS: O ATOR DA ENUNCIAÇÃO EXCESSIVO}

Os procedimentos que examinamos constroem um ator da enunciação que podemos chamar de excessivo, em oposição aos insuficientes ou aos que estão na justa medida. A linguagem do exagero, da hipérbole, do palavrão opõe-se à do comedimento, da elegância, da cortesia, que definem a justa medida nos discursos, mas também à linguagem sem graça e sem sabor, da insuficiência. Assim, quando o ator da enunciação é considerado, por exemplo, "exuberante", pode ser um elogio, quando o excesso se contrapõe à falta de graça e de sabor da insuficiência, ou uma ofensa, quando se distingue da linguagem comedida, isenta e elegante. Reinaldo Azevedo, em seu blog de 26/02/2016, na Revista Veja, toma como elogio ser chamado de "exuberante", por Patrícia Campos Mello, "esquecendo-se" do contexto em que isso foi dito:

Pautada para escrever sobre a mesa que debateu jornalismo de opinião, jornalista preferiu falar mal de mim... Mas não resistiu e me chamou de "exuberante"!!!

Maingueneau (1995) aponta três características do éthos ou do ator da enunciação, na metalinguagem semiótica: o caráter, o corpo e o tom ou voz. O ator da enunciação excessivo tem, nesses componentes, tendo em vista as análises 
realizadas: um caráter passional, sem medidas no exagero, autoritário, corajoso, descortês, deselegante, sem sutileza ou refinamento; um corpo atabalhoado, descontraído, vigoroso, viril; um tom ou voz estridente, acelerado, o do grito. A voz que grita, aparece também nos tipos de letras, cheias e maiúsculas, de grande dimensão, ou no uso de negritos e mesmo de letras vermelhas, nos discursos examinados, como no exemplo que segue, obtido no site do tio Astolfo:

\section{SE O CNPQPODE PATROCINAR UMAMARCHAPELADESCRIMINALIZAÇÃO DO ABORTO, ENTÃO EU TAMBÉM POSSO FAZER UMA MARCHA PELA DESCRIMINALIZAÇÃO DO ESTUPRO, COM DIREITO AO MANÍACO DO PARQUE E O CHAMPINHA.}

O excesso exacerbado constrói o ator da enunciação, nos discursos intolerantes analisados, quase como uma caricatura.

Esse ator da enunciação excessivo ocorre, em geral, nos discursos intolerantes, como foi apontado, mas também pode aparecer em outros tipos de discursos do exagero, que não são obrigatoriamente intolerantes.Podemos aproximar, entre outras possibilidades, esse ator intolerante excessivo do da enunciação da imprensa dita sensacionalista, conforme descrito por Discini (2003:117-153) e Fiorin (2015: 229-230). Em ambos, há um ator da enunciação excessivo, tal como foi aqui examinado.

Resta dizer que, de forma às vezes menos caricatural do que nos blogs mencionados, esse ator da enunciação intolerante e excessivo pode ser identificado nos discursos de jornalistas em blogs ligados a jornais ou revistas da chamada "imprensa séria", como no exemplo que segue, extraído do blog já mencionado de Reinaldo Azevedo, na Revista Veja, com que concluímos nossas reflexões:

SEMINÁRIO NA FOLHA - Patrícia Campos Mello lamenta debate civilizado, sem sangue. Ela queria porradaria!

Pautada para escrever sobre a mesa que debateu jornalismo de opinião, jornalista preferiu falar mal de mim... Mas não resistiu e me chamou de "exuberante"!!!

No final do texto, o jornalista diz ainda:

Encerro. Patrícia: exuberante estava você! Os cabelos louros sobre o tecido azul enfeitavam aquele palco.

Os comentários dos leitores do blog acentuam, ainda mais,o discurso excessivo do jornalista, inclusive a deixa machista dos cabelos louros:

\section{ICONOCLASTA}

Fevereiro 26, 2016 às 8:38pm

Parabéns,Reinaldo,comosempre!!!Graças a Deus ainda existe gente como você neste País, mas são muito poucos, infelizmente.E até quando vamos ter que conviver com esses ativistas vermelhos disfarçados de "jornalistas"? Gentalha escrota!

Avós do Brasil

Fevereiro 26, 2016 às 6:34pm

Ô Reinaldo!! Essa moça ...ficou tendo alucinações? Tão bonita e tão desligada do tema em debate. Talvez seja a cor do cabelo. As afirmações dessa jornaleira pecam pela "desonestidade 
intelectual", por se dissociarem dos fatos tratados no encontro. Acho que ela não consegue disfarçar uma inveja mal contida de sua capacidade de facilmente jogar por terra as boçalidades que esses energúmenos de esquerda são capazes de verter pela latrina que possuem no lugar da boca.

\section{JANSCER NOMURA}

Fevereiro 26, 2016 às 3:40pm

Mediante aos fatos, fica claro que essa senhora, se hoje trabalha na folha, é por causa dos seus lindos cabelos loiros como citado nesse texto. [...] quem sabe ela teriamais sucesso nas colunas de classificados — acho mais a cara dela!

\section{$\overline{\text { REFERÊNCIAS BIBLIOGRÁFICAS }}$}

BARROS, D. L. P. de (2000). Entre a fala e a escrita: algumas reflexões sobre as posições intermediárias. In: Preti, D. Fala e escrita em questão. São Paulo: Humanitas, p. 57-77.

BARROS, D. L. P. de (2006). Efeitos de oralidade no texto escrito. In: Preti, D. Oralidade em diferentes discursos. São Paulo: Humanitas, p. 57-84.

BARROS, D. L. P. de (2008a). Preconceito e intolerância em gramáticas do português. In: D. L. P. de BARROS. D. L. P. de e FIORIN, J. L. (orgs) A fabricação dos sentidos - estudos em homenagem a IzidoroBlikstein. Ed. São Paulo: Humanitas, v. 1, p. 339-363.

BARROS, D. L. P. de (2008b). A identidade intolerante no discurso separatista. Filologia e Lingüística Portuguesa, v. 9, p. 147-167.

BARROS, D. L. P. de (2008c). Discurso, indivíduo e sociedade: preconceito e intolerância em relação à linguagem. In: $O$ discurso nos domínios da linguagem e da história. São Carlos - SP: Ed. Claraluz, v. 1.

BARROS, D. L. P. de (2011). A construção discursiva dos discursos intolerantes. In: BARROS, D. L. P. de. Preconceito e intolerância. Reflexões linguístico-discursivas. São Paulo: Editora Mackenzie, p.255-270.

BARROS, D. L. P. de (2013). Política e intolerância. In: FULANETI, O. N. e BUENO, A. M. (orgs.). Linguagem e política: princípios teórico-discursivos. São Paulo: Contexto, p.71- 92.

BUENO, A. M. (2014). Intolerância, preconceito e exclusão. In: LARA, G. P. e LIMBERTI, R. P. (orgs.). Discurso e (des)igualdade social. São Paulo: Contexto, p.61-78.

DISCINI, N. (2003). O estilo nos textos. São Paulo: Contexto.

FIORIN, J. L. (1988a). O regime de 1964. São Paulo: Atual.

FIORIN, J. L. (1988b). Linguagem e ideologia. São Paulo: Ática.

FIORIN, J. L. (1992). Algumas considerações sobre o medo e a vergonha. Cruzeiro Semiótico, no 16, p.55-63.

FIORIN, J. L. (1996). As astúcias da enunciação. São Paulo: Ática.

FIORIN, J. L. (2014). Figuras de retórica. São Paulo: Contexto.

FIORIN, José Luiz (2015). Argumentação. São Paulo: Contexto. 
BARROS - Estudos discursivos da intolerância: o ator da enunciação excessivo

GREIMAS, A. J. (1983). Sobre o sentido II. São Paulo: Nankin/EDUSP. 2014

GREIMAS, A. J. e COURTÉS, J.(1979). Dicionário de Semiótica. São Paulo: Contexto. 2008.

GREIMAS, A. J. e FONTANILlE, J. (1991). Semiótica das paixões. São Paulo, Ática.1993.

LANDOWSKI, E. (1979). Du politique au politologique. In: Greimas, A. J. et LANDOWSKI, E. Introduction à l'analyse du discours en sciences sociales. Paris: Hachette, p. 103-127.

LANDOWSKI, E. (1982). Les discours du pouvoir. In: J-C Coquet. Sémiotique L'école de Paris. Paris: Hachette, p. 151-172.

LANDOWSKI, E. (1992). A sociedade refletida: ensaios de sociossemiótica. São Paulo: EDUC/Pontes (original francês de 1989).

LANDOWSKI, E. (1997). Présences de l'autre. Paris, PUF.

LOTMAN, I. M. (1981). Semiótica dos conceitos de "vergonha" e "medo". In: LOTMAN, I. M. et al. Ensaios de semiótica soviética, Lisboa: Horizonte, p. 237-240.

ZILBERBERG, C. (2004). As condições semióticas da mestiçagem. In: CAÑIZAL, E. P. e K. E. CAETANO, K. E. (orgs.). O olhar à deriva: mídia, significação e cultura. São Paulo : Annablume.

ZILBERBERG, C. (2006a). Éléments de grammaire tensive, Limoges : Pulim.

ZILBERBERG, C. (2006b). Síntese da gramática tensiva. Significação 25, p.163-204. 